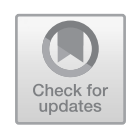

\title{
Between the Nonhuman and Inhuman: The Challenge of the Posthuman for Art|Education in the Twenty-First Century
}

The oeuvre of Deleuze and Guattari offers artists, educators, and curators a rich body of work to pursue ethical and political dimensions of visual art in what they call societies of control. These are societies where time and space are modulated through virtually invisible means utilizing the latest smart technologies, and where mathematical algorithms set the parameters of what is and is not possible. Big Data via corporate interests shapes our technological imagination as to how we are supposed to live. It is our 'elephant in the room.'

Such a situation addresses a core competency of the twenty-first century: the way art and design education must grapple with the changes designer capitalism has undergone. For artists and designers alike, this means a designer mentality that has become more and more dominant for their livelihood as we live in a world mediated by screen images, already discussed in previous chapters. The Maker Movement, which calls for a DYI approach to electronic engineering as championed by Massimo Banzi's Arduino project (2012), for example, enables all sorts of interesting inventions to be made by those who have had no 'formal training' in design engineering. But, it should be no surprise that the copyrights for the best products invented in so many 'start-up' businesses are bought by large corporations. Designer capitalism requires programmers and design engineers to continue economic growth. Educational curriculum reforms in post-industrialized societies of control such as England, the United States, Canada, China, and Australia, to

j. jagodzinski, Pedagogical Explorations in a Posthuman Age,

Palgrave Studies in Educational Futures, https://doi.org/10.1007/978-3-030-48618-1_12 
name a few, have instituted programming at the elementary grades so that the very young become data savvy. As we know, the Science, Technology, Engineering, and Mathematics(STEM), which makes up the core of such initiative for design, has been lobbied by art educators to include art as part of this movement known as STEAM, to little avail when it comes to funding through grants. STEAM would need to be re-orientated to the state of the Anthropocene that shifts economic priorities to the values of what has been called 'commonism' (Dardot and Laval 2019) where the basic elements that have no boundaries, such as water, land, and air, become a global responsibility to be cared for and carefully monitored for global health. Such a dream, while far away, can be realized after such a devastating pandemic like COVID-19.

In this chapter, I want to explore two things: the first is Big Data, what I refer to as the inbuman in my title, and to touch on the nonhuman which, in recent literature, points to the vibrations of matter itself (Barad 2007; Bennett 2010). By inhuman, I refer to technologies that have shaped human capacities, or what is often referred to as technogenesis (Hayles 2012; Stiegler 1998; Simondon 2016). Derrida (1976) referred to this same development as grammatology, which seems to collapse everything into 'text.' His claim that "there of nothing outside the text," is too limiting. In contrast, the nonhuman in Deleuze and Guattari's terms refers and extends the range to affects and percepts. As they write in What is Philosophy? "the percept is the landscape before man, in the absence of man [...] Affects are precisely these nonhuman becomings of man, just as percepts - including the town-are nonhuman landscapes of nature" (1994: 169).

Nonhuman extends into inorganic life for Deleuze and Guattari. It is not confined to the organic sphere; life in this realm is closer to Zö̈ than bios, and it refers to virtuality, the potential that may be actualized by 'releasing' life. This distinction I am making is not maintained in the broad literature when it comes to thinking the nonhuman. Some authors recognize this difference between inhuman and nonhuman but simply do not state it (Barnet 2004). Inhuman, as I am thinking it through, is closer to Michel Serres (see Moser 2016) notion of exo-Darwinism, which is the reprogramming of the senses as each new technology is invented that affects and effects the 'human' body reciprocally, both physiologically and psychically. To recall Chapter 9 when reviewing infant synaesthesia: it is possible now, with the help of technologies like fMRI to isolate specific areas of the brain, to link otherwise 
separate domains of senses such as 'seeing' with the 'tongue.' Peter Weibel (2015) uses the term 'exo-evolution' to identify the processes of technology being able to cross-reference our senses. The invention of the Josephson Junction of superconductivity has made it possible to form a bridge or 'junction' between natural and artificial nerve cells. This has enabled a revolution in thinking how the brain can be 'rewired.' Its neuroplasticity - the capacity of synapses, nerve cells to change their functions-enables quite literally the development of cyborgian body where it has been possible for blind people to 'see' with their tongue via an instrument called a BrainPort invented by Paul Bach-y-Rita in 1998. Reprogramming sensory life in the processing of data by the brain is now a reality.

The affective turn has spread throughout all disciplines and the hallmark of relational ontology has been 'affect' and 'becoming.' Multiple ontologies are now called on (Paleček and Risjord 2013). In the more conservative circles, affect is treated as emotion (the emotional brain) and 'becoming' simply another form of social transformation. Deleuze and Guattari had already developed the more radical position through their machinic philosophy. Affects and percepts are understood as being autonomous entities - inorganic - and 'becoming' is grasped as an 'event' that deterritorializes entities in an assemblage. The nonhuman and the inhuman both shape what it is to be human-better understood as what is now called the 'posthuman' with its competing definitions that include the transhuman and the 'human' as thought through the lens of neoliberalist thought. This latter development should be identified as 'posthumanism,' a continuation of humanist developments in contrast to the posthuman with its attempts to decenter the human.

Let me begin with the inhuman - and the question of Big Data as information that art and design educators need to visualize, which is the dominant mode of modulating and controlling movement and time in control societies. The question to ask when it comes to Big Data: What should art|educators worry about especially in the way images and digital information is related? Big Data refers to what one can do with large-scale data that cannot be done with smaller batches, to extract new insights or create new forms of value in ways that change markets, organizations, the relationship between citizen and governments, and more for our purposes, the perception of images today that interest artists and educators (see, for instance, Andrejevic 2013). 
Contemporary Big Data Banks are well protected both physically and cybernetically secured. The headquarters of Bahnhof, a Swedish Internet Service (ISP) provider, the former home of WikiLeaks, is located 30 meters (100 feet) under the granite rocks of Vita Berg Park in Stockholm. The location was a former nuclear bunker and command center during the Cold War. Internet companies like Google process more than 24 petabytes of data per day. 1 petabyte is 1 million gigabytes. In 2007, it was estimated that there was about 300 exabytes of stored data. Astounding when one exabyte is equal to one billion gigabytes! (Techorunch 2008). These numbers are unfathomable and sublime. They cannot be comprehended. The core of Big Data is prediction. It's the application of mathematics to huge quantities of data in order to infer probabilities and not potentialities and possibilities. Potentialities and possibilities belong to the virtual realm of all things.

The various modeling predictions that took place during the COVID pandemic is a good example of the way Big Data outcomes are projected depending on what statistical numbers are supplied, and how 'good' the data is. For instance, Dr. Deborah Birx, one of Trump's top official advisors, reported as of April 2, 2020, that $50 \%$ of the data for the coronavirus tests was missing. Not all the states had reported in. The televised charts presented could not be trusted. Virtual factors, all of which are lumped together under what behaviors the populace will take (distancing, washing hands, wearing masks, isolating, equipment available, and so on) are not part of these outcomes. We don't know which virtual multiplicities will be actualized.

Big Data research calls for self-correcting autopoietic systems that can augment or replace the fallibility of human judgment, like smart cars that can drive themselves, the environment is constantly 'read' via information flows so that such a 'smart' car, for example, can respond to each situation and even 'learn' from it: thus its 'smart' car status. The application of Big Data takes human judgment out of making recommendations, diagnosing certain illnesses, and recommending certain treatments. The central message of COVID is "stay home," isolate, and keep distance. Such proclamations of judgment are not prophetic but prophylactic. For that to take place requires the cinematic science-fiction world of Minority Report where 'criminals' are identified before they commit their crime. They are magically identified through the clairvoyant networking of three "pre-cogs." It is they who are capable of grasping the virtual dimension and not Big Data. 
No human, however, is able to outplay a computer at chess as we saw Garry Kasparov lose to the supercomputer Big Blue. Humans are, however, better at the game of Jeopardy where guesswork and memory are still involved. Watson, the computer lost. But, then there was the matchup with the world champion of the game Go, 9 dan ranked Ke Jie of China, who lost three consequent games to Google's AlphaGo. It was so devastating that Ke Jie decided to give the game up. China and Korea have the best Go payers in the world. Despite these 'smart machines,' there seems to be little comfort in the complexity of urban living when it comes to banking, finance, and health. Such complexity is now navigated via machinic thought. Machines 'talk' to one another at supra-human speed without our knowledge and comprehension of such coded language. Inhuman seems to be the proper descriptor for AI in such cases. 'Terminator-type' movies that directly address the anxiety of AI's superiority seem plentiful. Star Trek: Picard ends its first season with Picard becoming a "synth."

The use of Big Data is applied to be given a sense of direction, to gain insight into the macro-level, to predict future scenarios. Causes are not what is searched for, rather patterns and correlations within the sifted data that have been mined and gathered constitute results from which policy is then extrapolated. It is about what is happening, not why it is happening, and that it is happening. 'Real time,' so to speak. Big Data, in short can identify more accurately the 'control' needed in a managed society that Deleuze and Guattari address. Big Data has become a significant corporate asset to set economic plans in motion, as well as enabling the use of algorithms throughout the designer world, a development that has been carefully explored and critiqued through the many writings of Luciana Parisi (see, for instance, Parisi 2013).

Perhaps more unnerving is the continual mapping of the body via datafication. By this, I mean both the extrinsic and intrinsic human body. The extrinsic body refers to "quantified self-movement," initiated by fitness aficionados, medical maniacs, and tech junkies who measure every element of their bodies output so as to live 'better,' better referring to controlling and managing their energy expenditures in the environment: calorie intakes, steps taken during the day, power meters, and so on. The intrinsic body (or affective body) is being tapped as well. You can now track sleep patterns by measuring brainwaves, or have a GPS system that tracks a sensor attached to an asthma inhaler to warn you of environmental triggers that can bring about an asthma attack; you can 
buy a wristband that monitors your vital signs like heart rate and skin conductivity so you know how stressed you are. There is an app, which can be installed on your smartphone that enables you to monitor a body's tremors for Parkinson's disease and other neurological disorders. You can even generate a networked social map that shows how Linked-In you are with others.

The point to be made here is that both the conscious and unconscious thoughts, both intrinsic and extrinsic body sensations are now being exteriorized through digitalized technologies. The future manufacture of avatars is said to increase in complexity and sophistication due to the proliferation of such research. In 2045, a hologram-like avatar is projected, like the hologram Doctor on the television series Star Trek: Voyager. This has now been 'one-bettered' by a number of holographic variations of captain Cristóbol Rios of Star Trek: Picard, each with a task to perform on board his spaceship. It is unlikely that such design engineering developments are likely to stop before such seemingly impossible goal is reached. The desire is there. What this means is that all Life as $Z o \ddot{e}$ - as nonhuman (inorganic) or 'free' life-is being captured as bios, captured through hyper-capitalist research, production, and expansion, which is then packaged and sold back to us. Creative energy (Zö̈) comes with a price tag, metaphorically like the commercial energy drinks (Red Bull, Monster Energy, Full Throttle) that promise an explosion of Zö̈ once they have been consumed. In short, the human is reduced to an object of technological manipulation and is no longer properly 'human' as we once thought. This presents the paradox now famously made by Bruno Latour (1993): we have never been modern from the start but have modified our species through our invented technologies. There is no hard distinction between nature and culture, and never has been. The eoliths, tools used by the various Australopithecus species that have been discovered thus far (afarensis, africanus, anamensis, sediba, and robustus), were a factor in modifying their brain/body physiology and cognition.

We can also look to Bernard Stiegler's (1998) stance by recognizing what he calls the epiphylogenic development of our species according to the logic of prosthetic supplementation. This has led us to a point where the industrialization of memory leads to a loss of individuation (see Chapter 6), the inability to create outside of these technologies of control, the data banks that archive knowledge, which perpetuate the 
illusion of participation, democracy and 'free' play, and the capturing of "tertiary memory," or mnemotechnics as suggested by Stiegler. "Savoir-faire," the knowledge of how to make do in the Marxist sense, is now being replaced with "savoir-vivre," the knowledge as to "how to live" based on psycho-technological apparatuses that capture and package life as bios. Even the Maker Movement referred to earlier, which does enable free experimentation to release the Life of Zoë is being harnessed by corporations.

I would like to look at one example where image impact and information come together to show that the excess of Zoë as nonhuman life always escapes the capturing of life through capitalist means of inhuman biopower as theorized by the late Michel Foucault (1978). In my own work (for instance, jagodzinski 2010), I differentiate machinic technologies of Macht pervaded by biopower from machinic technologies of Lassen, technologies that enable a release of the 'free' life of Zö̈, which belongs to the virtuality of all things. This was a distinction first made by Martin Heidegger and later explored by Krzysztof Ziarek (2013).

Machinic technologies of Lassen tap into creative potential so that the future is not closed by a control society as envisioned by capitalist grasp of Big Data. An example here is Fabio Lattanzi Antinori's The Obelisk (2012), a circular sculpture placed on a pedestal that changes color from opaque to transparent according to four main crimes that are committed against peace: genocide, crimes against humanity, crimes of aggression, and crimes of war. The color changes depend on 'current' online news data that is 'fed' into this sculpture as it processes and translates the data. (Copyright prevents me from showing the image, but an Internet search readily shows a number of angles of this sculpture.) The assemblage technology of Lattanzi Antinori's sculpture deterritorializes, as Deleuze and Guattari put it, the datafication that is constantly capturing attention and affecting extrinsic and intrinsic bodies, and marketing that experience as bios. In this view, the exchange of Life as Zö and Bios forms a never-ending becoming of transformation pervaded by ethical and political values. The danger is that any release of Zö̈ through deterritorialization in a capitalist system is always dependent on economics where profit dollars are the issue, not necessarily the health of our species or the planet. The Obelisk is a beacon giving us a state of our global health. Its technology is enabling (lassen) and not controlling. 


\section{The Visible Human Project (VHP)}

The Visible Human Project (VHP) (for images, simple search the Internet for this project) offers perhaps the best example of Big Data in service of biopower for surgical planning and visual pedagogy. In my view, this is an example of Macht technology. In a nutshell, this is an archival project where a data set of an entire human male and female cadaver was rendered as a three-dimensional image utilizing Computed Assisted Tomography (CAT) and Magnetic Resonance Interferometry (MRI). MRI and CAT are the new visual technologies of datafication. These visual digitalized technologies have become new ways of surveying the body as well as the brain. They are both beneficial and detrimental in the way visual information provided is interpreted and applied. When it comes to neurological research, in many cases equating specific emotions to specific parts of the brain, interpretive scans come dangerously close to phrenological research of the nineteenth century. The sole use of fMRI to make projective determinations concerning mental health has been flagged for its uncertainties.

Issues of visibility, the rendering and management of the body's interior, the relations of part to whole and between the normal and pathological, all come into play in this VHP project. The cadaver selected to be the first man into digital space, preserved indefinitely, was a convicted criminal, 39-year-old Joseph Jernigan who had signed a donor consent form making his corpse available for scientific research, despite an appendectomy and a missing tooth. Physiologically, as a specimen he was certainly less than 'perfect' in this sense. The transformation of his body into digital data required placing the cadaver in an MRI machine to be fully scanned, which then provided the needed template. The cadaver was then frozen in blue gelatine at $-85^{\circ} \mathrm{C}$. Once suitably solid, it was then cut into four sections. Each section was then CAT and MRI scanned. The cadaver was then planed (cut) into 1-mm intervals. Each body section was digitally photographed, so that each photograph registered a small move through the body's mass.

1878 slices, each slice was a 24-bit digitalized colored image, and when put together composed 15 gigabytes of computer space, equivalent to 23 CD-ROMs. That was back in 1994. These slices could be restacked and manipulated via so-called computer 'flythroughs' to explore specific organs and body parts. The data set allowed organs to be isolated, dissected, and orbited; sheets of muscle and layers of fat and 
skin could be lifted away, and bone structures could be isolated. More animation and computer simulation have now been introduced to make the visual more 'alive,' going beyond mere color play and resolution. As a body archive of visual data, it could then become 'shareware' for any medical lab who wanted to buy and use it. Its transmissibility-the quality of telematicity-is inscribed in the data itself, and it has particular agential powers.

The VHP, which effectively is a virtual cyber-body, is a biotechnology that is meant to aid the 'live body' for therapeutic ends-the improvement of health and medical education, for more accurate imaging and removal of tumors or organ malformations, the planning and rehearsal of new surgical procedures such as telesurgery and keyhole surgery, and so on. The comparison that is made from an image-object (i.e., the virtual cyber-body) to a 'real' body-object (i.e., an actual patient), and then back again in a continuous circuit of referencing, establishes a startling relation. The VHP not only creates an archive of knowledge about the human body, but it also asserts that the body is itself an archive and an organic form of storage and replication. This is not simply a metaphor. The procedures of the VHP literally make the body an archive. It is a way to itemize and index an actual human body composed of finite content, open to multiple forms of ordering and modes of retrieval.

As Martin Heidegger (1977) presupposed, bio-scientific ways of modeling and understanding the order of living matter carry with them the means of instrumentation. This link between art and science goes back to the Renaissance. This means, on the one hand, understanding the human body as database or information archive is metaphorical. On the other hand, this very mode of understanding produces material practices that work the body as simply a database. In short, this is medicine's structuring fantasy of perfect management where living bodies predictably embody the application of biomedical techniques that are developed utilizing Big Data research like the VHP. This is paradigmatic for Macht technologies.

The fantasy of biomedicine is that matter is somehow programmable; the desire is to order materiality according to algorithmic efficiencies of the computer and the shutting out of Life as Zö̈. The VHP from this perspective is a form of medical pornography providing an inexhaustible satisfaction to fulfill that desire. The medical gaze is capable of seeing 'everything' there is to see in and through the body. Life here, 
designated as bios and information, act as synonymous terms. In the VHP, we see how form supplants matter. If the materiality of the flesh, or 'meat' as science fiction writers refer to it, the density, recalcitrance, palpability, and opacity of flesh were considered positive values, then the production of VHP figures could be evaluated as a violent procedure, the annihilation of body substance valued only for the production of a navigable spectacle. In the form/matter distinction, the only significance of matter for anatomy is its yielding of form for the medical gaze. The palatability of matter, that is, its ability to encounter and resist touch, is simple an obstacle to the eye, an inert and incidental biomass. It is matter as $Z o \ddot{e}$ that is being ignored and thus the need for other medical imaginaries. It is interesting to note that as the number of actual cadavers being dissected by hand drops, the more fine-motor hand skills are lost as the necessary neuronal circuits atrophy. It was André Leroi-Gourhan (1993) who warned: when the hand loses its importance, crafts(person) ship also fades, and begins to be carried out by media machines. This de-manualization of art is a sure sign of decay. We might say that such skill has migrated to the two thumbs used exclusively for texting on cell phones. Ganglia growth that connects those neuronal circuits is certain to be strengthened and thickened.

The VHP exemplifies the Aristotelian tradition of hylomorphism-the notion that matter obeys laws imposed on it from the outside. Life as bios forwards form, the categorization of parts and pieces by way of the iconic form of the body, animated by speeding up and arresting the body's cycles or capacities. What continually is excluded is the becoming of Life as $Z o \ddot{e}$, which is the time of becoming, organic time of death and decomposition-the nonhuman or inorganic in Deleuze and Guattari's terms. In short 'death' as the entropy of the organism is made amenable to the virtual time of computed space - the time of storage, retrieval, morphing, and computer serialization as in any videogame. The data object can be destroyed and then restored, repeated, deleted, deformed and reformed, morphed from one form into another without damage, loss or labor, just like in a videogame. There is only cyber-death as when an avatar disappears on the screen. Virtual computer time is a negentropic eternity-no death is ever felt. In all those operations, Life as Zö̈ - the nonhumandoes not enter into the process; entropic time does not exist. Yet, the baunt of the criminal Jerrigan does not go away from this project, but this is another story that brings to the surface historical traces that ethically insist on the past. The virtual (which is real) is again missing. 
To end this section with perhaps an obvious claim: the aesthetics of the VHP, which is generalizable to all hylomorphic thought, presents a view of biomedical health based on Big Data where the diseased living body can potentially return to its original condition of equilibrium or homeostasis from which it departs, and the problem of death postponed. It is life-in-death that pervades the biomedical imagination. Such an aesthetics defends against the full recognition of the hypercomplex formation of the living organism characterized by iatrogenic illness-that is, the flux and eddy of health and illness that characterizes the uncertainty of any medical intervention into a field of disease. This realization stares us in the face in the flux of the 2020 COVID pandemic. Deaths are Real.

The recognition of $Z o \ddot{e}$ as a perpetual movement of non-reversible imbalance, an aleatory, and uncertain flow and, of course, the irreversibility of an organism's being toward death become less of an issue for the biomedical gaze. Humans, like homeorhetic dynamic assemblages, are fluid not static systems, singularities modified by both inhuman and nonhuman entities-by the bacteria and viruses that live within us, and the technologies that modify us. This dimension attaches us to the creaturely life of the Cosmos and dark matter, which Deleuze and Guattari refer to as the inorganic $(Z o \ddot{e})$. The VHP is paradigmatic of posthumanist developments of mastery over matter as part of the Big Data craze in control societies, rather than posthuman developments that recognize the precarity of all living organisms-that is Life as Zö̈ that is so crucial due to climate change, the era of the Anthropocene, and pandemic catastrophes.

\section{Design Pedagogy}

I end this chapter with the importance of recognizing that 'life,' referred to as free energy of Zö̈ is what artists and art educators must address and keep in mind. I refer to this life as the nonhuman, as opposed to the inhuman of algorithmic Big Data. Zö̈ as nonhuman life needs to be constantly forwarded. This is not to say that I am supporting an either/or binary: Zö̈ or bios; analog or digital; continuous or discontinuous. No. Analog is not 'superior' to digital, both are in play. It is a matter of recognizing the status of this 'play' in every assemblage. In the VHP, the digital supersedes the analog. A Macht technology overwhelms the materiality of flesh as the cadaver vanishes. In distinction, operating rooms are exemplars where enabling technologies (Lassen) are inseparable from the body in which they intervene to save lives. Yet, the 
encroachment of AI technologies into ehealthcare systems as Macht technologies via body area networks (BAN) cannot be ignored (Peterson \& Iliadis 2020). In the contemporary world, pervaded by climate change, only an ecological consciousness can off-set the pervasive technological instrumentalized imaginary. One way to do this is to overcome the hylomorphism by pointing to artists and designers who have embraced science, but have done so in ways that overcome the false division between culture and nature, embracing the technologies of Lassen as the freeing up of Zö̈.

The contemporary situation that design pedagogy faces is one where there is a finitude of planetary resources. All those minerals and fabricated plastics that are needed to constantly innovate computerized technologies are presenting significant geopolitical problems. Jussi Parikka (2014) has called this the 'Anthrobscene.' Certain minerals are not easily mined due to the politics between corporations and national states, as weak as some of those states are. It is a 'no brainer' that the anthropocentric activities of Man are changing the global climate where the 6th extinction of our species is now occurring; the way food is grown and distributed via global trade agreements and global capital means that the growing global population cannot be fed within these capitalist distributive systems.

The ravages of war and terrorism have become a permanent feature of everyday life in Syria and Yemen, and globally as well. This has led to massive refugee and asylum seekers flooding into the post-industrial countries, a factor that global capitalism cannot control. The conflict over natural resources, especially water, and the constant air pollution in countries such as China raises basic issues of sustainability of the human body. We can add to this list of 'capitalist woes': unemployment, homelessness, trade-wars, resource conflicts, foreign debt, arms trades, nuclear weapons, and inter-ethnic violence. Worse, perhaps is that there has been a significant shift toward fascist regimes and right-wing populist politics globally. The election of Donald Trump as the 45th President of the United States has worried what is already a precarious global order - then a Covid pandemic to ensure true confusion and devastation. Against this backdrop designing for designer capitalism seems like folly, and art and its education need to recognize this global precariousness to educate our children otherwise.

There are several designers that art educators can turn to address this situation. For designers such as Tony Fry $(2009,2010,2012)$, 'sustainability' is not understood in terms of capitalist design, but sustainability as 
the necessity of ontologically designing ourselves, as we, as a species have blindly done until reaching this critical point of anthropogenic change. This requires making a world-within-the-world other than as it currently exists. Design education at all levels has to wean itself off its current entrapment with the corporate world of designer capitalism for nonsustainable life as presented in Chapters 6 and 7.

Sustainability is about the ability to create so as to keep up generative connections; these connections can only arise out of differential relations that will maintain an intensity to continue to generate difference. This is most certainly a twenty-first-century core competency. While there is no running away from current technologies, science and art can come together in different sustainable ways. There are a number of designers, artists, and architects who are working with scientists across a wide variety of fields who have questioned the hylomorphic thinking where form is imposed on nature, often by brute force, what is often referred to as a 'heat, beat, treat' process, which uses up $96 \%$ of the material that results in waste but produces only $4 \%$ of the product!

The work of Rachel Armstrong (2015) in collaboration with Christian Kerrigan is an outstanding paradigmatic example where the nature|culture divide no longer holds as the attempt is to develop living systems of their own invention that are able to symbiotically come together to create sustainable structures, for instance the project to prevent Venice from sinking (Hobson 2014). This is an excellent example of lassen-technology. Rachel Armstrong's thrust here is to develop 'living architecture'-that is self-repairing architecture through 'protocell' technologies. Together, with other chemists and scientists, Armstrong and her colleagues are able to manipulate these 'protocells,' which have properties of living systems, so that a new form of architecture emerges free of hylomorphism. Projects include attempting to prevent Venice from sinking by having these metabolic materials grow a limestone reef around the aging and rotting wood. While this is not an overnight process, it is a sustainable project.

In 2013, the EDF Foundation in Paris presented an exhibition that drew artists together who demonstrated this geo-biological turn (see ULGC 2013). The shift in paradigmatic thinking to understand 'distributive agencies' is well on its way. The realization has come that the nonhuman world and the inhuman world of artificial intelligence or smart technologies possess 'agentic capacities' and must be understood symbiotically and put to use. An attunement with Nature is necessary and urgent. Human action is conditioned by a manifold of social, 
material, institutional, and corporeal factors that come together as assemblages that are held together through desire. This is in keeping with the machinic thought of Deleuze and Guattari. Such an understanding is beginning to pervade all the sciences as a direct effort by well-known pioneers such as Bruno Latour, Donna Haraway, and Katherine Hayles to note the most prominent and often quoted.

There is no 'pure' Nature that has not already been altered. As Bruce Sterling (2000) the founder of the Viridian Design Movement maintains, there is not a liter of seawater anywhere without its share of polychlorinated biphenyls (PCBs). New microscopic bacteria have now been discovered that thrive on plastic waste thrown in our oceans. The entanglement between the technologies of Nature and technologies of culture fold over each other; they are no longer separate spheres. There is no 'nature' per se. It becomes 'ecology without nature' as argued forcefully by Timothy Morton (2009). Brute force (hylocentrism) has been the previous approach to issues of bioenergy (oil, coal, gas); the shift with biological design treats the cell as the hardware and the genes as the software. Life becomes a code that is interchangeable, depending on the manipulation, to produce energy for specific purposes. It can become energy, food, and fiber, analogous to what is happening in the domain of stem cell research. It is possible to transfer genes from one cell to another to create new species. Here, Zoë and bios work together symbiotically as both genetics and genetic drift are accounted for. Nanotechnologies, for example, are used to purify water. Given that water continues to be a growing problem, desalination becomes possible by making water filters with carbon nanotubes; it is possible to remove salt from saltwater without the need to apply extreme high pressure to force water through conventional semipermeable filters. Nanotechnology overcomes hylomorphic mentality as well. Again, I would see these as exemplars of 'lassen-technologies.'

Biomimicry as championed by Janine Benyus (2002, 2009b) offers many examples of design that uses Nature as a guide. She offers a redesigning of the world based on the designs of Nature. "In a biomimetic world, we would manufacture the way animals and plants do, using sun and simple compounds to produce totally biodegradable fibers, ceramics, plastics, and chemicals. Our farms, modeled on prairies, would be self-fertilizing and pest-resistant. To find new drugs or crops, we would consult animals and insects that have used plants for millions of years to keep themselves healthy and nourished. Even computing would take its 
cue from nature, with software that 'evolves' solutions, and hardware that uses the lock-and-key paradigm to compute by touch" (Benyus 2009a, online).

This emerging field of biomimicry, as it too moves away from hylomorphism, however, remains trapped within a capitalist economic system, bringing certain skepticism as to just how such design can address a planetary ecological consciousness in clever ways without addressing the ethico-politics means when doing so. But, perhaps this is the best hope we have now? The same question can also be extended to the ecological imagination as applied to 'vibrant architecture' by Rachel Armstrong (2008, 2015), which views building as part of (inhuman) computer programming that establishes a 'germline structure,' offering humans the potential to make genetic adjustments with a predictable lifecycle of the architecture once it is no longer responsive to human activity. It then decays in the ecosystem to be recycled by its progeny.

Currently, an ecological pedagogy of design that grapples with the very 'design' of our species via technologies (what I have called inhuman) and nonhuman forces of $Z o \ddot{e}$, as illustrated by the intermingling of art, design, and science via biomimicry, seems far from sight/cite/ site. However, it seems to me this is the way art education's imagination needs to go to help re-orientate the current direction of art and design education from its capitalist orientation to one that recognizes the forces that shape the Anthropocene. This seems to me to be a twenty-first-century imperative for art|educators. Without such a reorientation, what might be called an ecologics that supports an ecosophy in Félix Guattari's (2000) terms, it is unlikely that a new generation of children will be able to overcome a 'strictly' technologic (inhuman) mentality of Macht technologies as it is such a powerful force today, whereas it is precisely the combination of art/science/philosophy that is badly needed for post-conceptual art (Osborne 2013) that explores the anthropogenic production during this era of the Capitalocene (Moore 2017), yet another, more accurate term for what has been inappropriately popularized as the Anthropocene.

\section{REFERENCES}

Andrejevic, M. (2013). Infoglut: How too much information is changing the way we think and know. New York, NY: Routledge. 
Armstrong, R. (2008). Artificial evolution: A hands-off approach for architects. Neoplasmatic Design AD, 78(6), 86-89.

Armstrong, R. (2015). Vibrant architecture: Matter as a codesigner of living structures. Warsaw and Berlin: De Gruyter.

Banzi, M. (2012). How arduino is open-sourcing imagination| TED. Available at:https://www.ted.com/talks/massimo_banzi_how_arduino_is_open_ sourcing_imagination.

Barad, K. (2007). Meeting the universe halfway: Quantum physics and the entanglement of matter and meaning. Durham: Duke University Press.

Barnet, B. (2004). Technical machines and evolution. Ctheory.net. Available at: http://www.ctheory.net/articles.aspx?id=414.

Bennett, J. (2010). Vibrant matter: A political ecology of things. Durham: Duke University Press.

Benyus, J. (2002). Biomimicry: Innovation inspired by nature. New York: Perennial.

Benyus, J. (2009a). Biomimicry institute. Available at: https://biomimicry.org/ janine-benyus/.

Benyus, J. (2009b). Biomimicry in action| TED. Available art: https://www.ted. com/talks/janine_benyus_biomimicry_in_action.

Dardot, P., \& Laval, C. (2019). Common: On revolution in the 21st century. London: Bloomsbury Academic.

Deleuze, G., \& Guattari, F. (1994). What is philosophy? (H. Tomlinson, Trans.). New York, NY: Columbia University Press.

Derrida, J. (1976). Of grammatology (G. C. Spivak, Trans.). Baltimore: Johns Hopkins University Press.

Foucault, M. (1978). History of sexuality: An introduction (R. Hurley, Trans.). New York, NY: Random House.

Fry, T. (2009). Design futuring: Sustainability, ethics, and new practice. Oxford: Berg.

Fry, T. (2010). Design and politics. Oxford: Berg.

Fry, T. (2012). Futuring, the city \& sustainment-The remaking of design | TED. Available at: https://vimeo.com/36145380.

Guattari, F. (2000). The three ecologies (I. Pindar \& P. Sutton, Trans.). London and New Brunswick: Althone Press.

Hayles, K. N. (2012). How we think: Digital media and contemporary technogenesis. Chicago: University of Chicago Press.

Heidegger, M. (1977). The question concerning technology. In W. Lovitt (Trans.), The question concerning technology and other essays. New York, NY: Harper \& Row.

Hobson, B. (2014). Growing a 'giant artificial reef' could stop Venice sinking. Dezeen. Available at: https://www.dezeen.com/2014/05/30/movie-rachelarmstrong-future-venice-growing-giant-artificial-reef/. 
jagodzinski, j. (2010). Visual art and education in an era of designer capitalism: Deconstructing the oral eye. New York, NY: Palgrave Macmillan.

Latour, B. (1993). We have never been modern (P. Catherine, Trans.). Cambridge, MA: Harvard University Press.

Lattanzi Antinori, F. (2012). The Obelisk. Available at: https://theodi.org/ culture/obelisk-2012.

Leroi-Gourhan, A. (1993). The fate of the hand. In B. A. Bostock (Trans.), idem, Gesture and speech (pp. 255-256). Cambridge, MA: MIT Press.

Moore, J. (2017). The Capitalocene, Part 1: On the nature and origin of our ecological crisis. Journal of Peasant Studies, 44(3)L, 594-630.

Morton, T. (2009). Ecology without nature: Rethinking environmental aesthetics. Boston: Harvard University Press.

Moser, K. (2016). The encyclopedic philosophy of Michel Serres: Writing the modern work and anticipating the future. Augusta, GA: Anaphora Literary Press.

Osborne, P. (2013). Anywhere or not at all: Philosophy of contemporary art. London: Verso.

Paleček, M., \& Risjord, M. (2013). Relativism and the ontological turn within anthropology. Philosophy of the Social Sciences, 43(1), 3-23.

Parikka, J. (2014). Anthrobscene. Minneapolis, MN: University of Minnesota Press.

Parisi, L. (2013). Contagious Architecture: Computation, aesthetics, and space. Cambridge, MA: MIT Press.

Peterson, I. \& Iliadis, A. (Eds.). (2020). Embodied computing: Wearables, implantables, embeddables, ingestibles. Cambridge, MA: The MIT Press.

Simondon, G. (2016). On the mode of existence of technical objects (C. Malaspina, Trans.). Minneapolis: Univocal Press.

Sterling, B. (2000). Manifesto: Viridian design movement. Available at: http:// www.viridiandesign.org/manifesto.html.

Stiegler, B. (1998). Technics and time 1: The fault of Epimetheus (R. Beardsworth \& G. Collins, Trans.). Stanford, CA: Stanford University Press.

Techcrunch. (2008). Google processing 20,000 terabytes a day, and growing. Available at: https://techcrunch.com/2008/01/09/google-processing20000-terabytes-a-day-and-growing/.

ULGC. (2013). Making the geo-biological turn. Alive/En Vie. Aux Frontières du Design, at Espace EDF, Paris. Available at: http://urbanlabglobalcities.blogspot.com.br/2013/05/making-geo-biological-turn-aliveen-vie.html.

Weibel, P. (2015). The seeing tongue: New aspects of exo-Darwinism. Available at: https://schloss-post.com/the-seeing-tongue/.

Ziarek, K. (2013). Language after Heidegger. Bloomington: Indiana University Press. 